DOI: https://doi.org/10.24127/ajpm.v9i3.2950

\title{
REACT: STRATEGI PEMBELAJARAN UNTUK MENGEMBANGKAN KEMAMPUAN MAHASISWA DALAM MENGKONSTRUKSI BUKTI
}

\author{
Arif Hidayatul Khusna ${ }^{*}$ \\ ${ }^{1}$ Pendidikan Matematika, Universitas Muhammadiyah Malang, Malang, Indonesia \\ *Corresponding author. Universitas Muhammadiyah Malang, Malang, Indonesia. \\ E-mail: $\quad \underline{\text { khusna@umm.ac.id }}^{\left.1^{*}\right)}$
}

Received 18 July 2020; Received in revised form 07 September 2020; Accepted 17 September 2020

\begin{abstract}
Abstrak
Tujuan penelitian ini adalah untuk mendiskripsikan penerapan strategi REACT (Relating, Experiencing, Applying, Cooperating, Transferring) untuk mengembangkan kemampuan mahasiswa dalam mengkonstruksi bukti. Jenis penelitian yang digunakan adalah deskriptif dengan pendekatan kualitatif. Subjek penelitian adalah mahasiswa program studi pendidikan matematika yang sedang menempuh mata kuliah Analisis Real. Hasil peneltian adalah strategi yang diberikan berupa memberi kesempatan kepada mahasiswa untuk menghubungkan teorema satu dengan teorema lain (Relating), menuliskan kembali bukti sesuai dengan bahasa sendiri dan penggunaan bukti non formal sebagai bantuan (Experiencing), memanipulasi bentuk pernyataan berdasarkan prinsip logika dasar (Applying), saling memeriksa kebenaran proses pembuktian (Cooperating), dan membuktikan pernyataan yang dikembangkan (Transferring). REACT berdampak pada berkembangnya kemampuan mahasiswa dalam mengonstruksi bukti yaitu mahasiswa mampu menggunakan teroema sebelumnya untuk digunakan dalam proses pembuktian, melakukan manipulasi bentuk logika matematika sebagai strategi awal memulai proses pembuktian, menggunakan bantuan bukti non formal untuk menentukan langkah pembuktian selanjutnya, memeriksa kevalidan proses pembuktian dan mampu melakukan pembuktian kontradiksi.
\end{abstract}

Kata kunci: Pembuktian matematis; strategi REACT.

\begin{abstract}
The concern of this study is to describe the application of REACT (Relating, Experiencing, Applying, Cooperating, Transferring) strategies to develop students' abilities in constructing evidence. This type of research used is descriptive with a qualitative approach. The research subjects were students of mathematics education study programs who were taking Real Analysis courses. The result of the research is a strategy given in the form of allowing students to connect one theorem with another (Relating), rewriting evidence according to their language and using non-formal evidence as an aid (Experiencing), manipulating statement forms based on basic logic principles (Applying), checking the correctness of the verification process (cooperating), and proving the statements developed (Transferring). REACT has an impact on the development of students' abilities in constructing evidence, namely students can use the previous theorem to be used in the proving process, manipulate mathematical logic forms as an initial strategy to start the proof process, use non-formal evidence to determine the next step of evidence, check the validity of the proof process and be able to do a proof of contradiction.
\end{abstract}

Keywords: Mathematical proof; REACT strategy.

This is an open access article under the Creative Commons Attribution 4.0 International License

\section{PENDAHULUAN}

Matematika merupakan ilmu dasar yang memiliki karakteristik tertentu dibandingkan ilmu lain
(Verschaffel, Depaepe, \& De Corte, 2015). Beberapa disiplin ilmu lain seperti fisika, ekonomi, kedokteran, teknik, dan biologi menggunakan 
DOI: https://doi.org/10.24127/ajpm.v9i3.2950

matematika sebagai dasar pengembangan keilmuan (Srivastava \& Sutton, 2016)(Syah Aji, 2014). Diperlukan pemahaman yang mendalam untuk memahami matematika karena pada hakikatnya matematika memiliki konsep yang abstrak (Tambychik \& Meerah, 2010). Konsep abstrak matematika dituangkan dalam bentuk aksioma, definisi, postulat, teorema, lemma, dan corrolarry. Pada suatu materi, konsep-konsep tersebut tidak dapat berdiri sendiri melainkan terkait satu dengan yang lain. Keterkaitan antar konsep tersebut dapat terlihat ketika mahasiswa melakukan proses pembuktian. Proses pembuktian dapat dilakukan dengan beberapa teknik yaitu pembuktian langsung, kontrapositif, kontradiksi, dan induksi matematis (Hammack, 2013).

Pembuktian merupakan aktifitas inti dalam bermatematika (Soma Salim, 2019). Kemampuan membuktikan sangat penting untuk dikuasai untuk membantu membangun pemahaman matematika yang benar, logis dan sistematis (Pantaleon, Juniati, \& Lukito, 2018). Pembuktian merupakan aktivitas meyakini kebenaran suatu argument matematis (Switala, 2019). Aktivitas penalaran dan pembuktian haruslah menjadi pusat dari pengalaman matematika siswa (Stylianides, 2009).

Selain untuk menguji kebenaran pernyataan matematis, dalam matematika kegiatan pembuktian dapat digunakan untuk melatih berpikir logis yang merupakan ranah dalam pengetahuan matematika (Weinberg, 2019). Logis berarti setiap tahapan pembuktian harus didasari pada tahap sebelumnya. Aktivitas pembuktian dalam matematika memiliki tujuan untuk menguji pengetahuan atau pernyataan matematika seperti lema atau teorema. Kemampuan pembuktian penting untuk dikuasai karena kemampuan ini digunakan untuk memverifikasi, menganalisis, dan mengkomunikasikan kebenaran suatu argument, serta mensistematisasi pernyataan dalam bentuk aksiomatik (Bell, 1976). Pembuktian berfungsi sebagai alat untuk memvalidasi, menerima, memahami dan mengapresiasi pengetahuan matematika (Sørensen, Danielsen, \& Andersen, 2019). Sehingga dapat disimpulkan bahwa aktivitas pembuktian dalam matematika adalah proses deduksi dari asumsi (premis atau aksioma) dan pernyataan matematis (lema atau teorema).

Dilihat dari sudut pandang perkembangan kognitifnya, terdapat empat tahapan dalam merepresentasi bukti yaitu menguji kebenaran melalui pemanfaatan alat peraga maupun peragaan fisik (enactive proof), menguji kebenaran menggunakan gambar, grafik, atau tabel (visual proof), menguji melalui kegiatan manipulasi bentuk aljabar (symbolic proof), dan formal proof yaitu pengujian yang melibatkan penalaran deduktif (Tall, 1995). Beberapa metode pembuktian formal dalam matematika diantaranya adalah pembuktian langsung, pembuktian tak langsung, dan pembuktian dengan induksi matematik. Berdasarkan paparan di atas, aktivitas pembuktian formal memiliki dua prinsip yaitu (1) sistem aksioma dan premis, yang mendasari harus jelas, (2) setiap langkah harus disertai alasan deduktifnya.

Faktanya proses pembuktian merupakan hal yang tidak mudah untuk dilakukan (Ko, 2010)(Lesseig, Hine, $\mathrm{Na}$, \& Boardman, 2019). Fakta dilapangan menunjukkan 38 mahasiswa dari total 45 mahasiswa Prodi Pendidikan Matematika Universitas 
Muhammadiyah Malang mengalami kesulitan dalam melakukan proses pembuktian. Kesulitan utama yang dialami mahasiswa yaitu menentukan langkah-langkah dalam proses pembuktian. Selain itu dalam proses pembuktian, seringkali mahasiswa tidak menggunakan acuan disetiap langkahnya, sehingga berakibat menghasilkan alur pembuktian yang kurang tepat. Hasil beberapa riset juga menyatakan mahasiswa memiliki motivasi dalam melakukan proses pembuktian, tetapi mahasiswa mengalami ketidak yakinan ketika melakukan proses pembuktian (Reyhani, Hamidi, \& Kolahdouz, 2012)(Viholainen, Tossavainen, Viitala, \& Johansson, 2019)(Dogan, 2019). Rendahnya kompetensi matematika dan pandangan pesimis mahasiswa terhadap kegiatan pembuktian merupakan penyebab kesulitan mahasiswa dalam melakukan proses pembuktian (Healy \& Hoyles, 2000).

Kompetensi matematika erat kaitannya dengan pemahaman konsep tentang pembuktian dalam matematika. Diperlukan strategi pembelajaran khusus yang dapat mengubah pandangan serta pemahaman konsep mahasiswa terhadap hal yang berkaitan dengan proses pembuktian. Salah satu strategi yang dapat diterapkan adalah strategi REACT (Relating, Experiencing, Applying, Cooperating, Transferring). Strategi REACT menggunakan prinsip pembelajaran kontekstual dengan melibatkan siswa dalam aktivitas pembelajaran (Crawford, 2001). Relating berarti menghubungkan dengan situasi yang familiar bagi mahasiswa, Experiencing adalah kegiatan mengekplorasi dan penemuan, Applying kegiatan menggunakan konsep baru dalam konteks yang bermanfaat, Cooperating adalah kegiatan saling merespon dan berbagi informasi antar mahasiswa dan Transferring adalah belajar dalam konteks pengetahuan yang ada. Hasil penelitian (Ültay, Durukan, \& Ültay, 2015) (Jelatu, Sariyasa, \& Made Ardana, 2018) menyatakan bahwa strategi REACT berhasil dalam memahamkan suatu konsep. (Sari \& Darhim, 2020) menyatakan bahwa strategi REACT dapat digunakan untuk mengembangkan kemampuan penalaran siswa. Kemampuan penalaran inilah yang dibutuhkan dalam melakukan pembuktian dalam matematika. Sehingga penelitian ini, mencoba untuk menerapkan strategi REACT yang dapat mengembangkan kemampuan mahasiswa dalam mengkonstruksi bukti.

Berdasarkan hal tersebut, tujuan penelitian ini adalah untuk mendiskripsikan penerapan strategi REACT yang dapat mengembangkan kemampuan matematis mahasiswa dalam mengkonstruksi bukti.

\section{METODE PENELITIAN}

Jenis penelitian ini yaitu deskriptif dengan pendekatan kualitatif. Penelitian deskriptif kualitatif adalah penelitian yang didesain untuk menggambarkan fakta yang tampak dari objek peneliti. Dalam hal ini objek penelitian adalah pembelajaran dengan strategi REACT. Dalam penelitian kualitatif peran peneliti adalah sebagai instrumen kunci dimana dalam penelitian ini peneliti bertindak sebagai pengajar dalam proses pembelajaran.

Subjek penelitian adalah 45 mahasiswa Program Studi Pendidikan Matematika Unversitas Muhammadiyah Malang yang menempuh mata kuliah Analisis Real. Terdapat tiga tahapan prosedur penelitian yang dilakukan dalam penelitian ini yaitu (1) studi 
DOI: https://doi.org/10.24127/ajpm.v9i3.2950

pendahuluan, (2) perencanaan, (3) pelaksanaan. Studi pendahuluan dilakukan dengan mengkaji literatur tentang prinsip strategi REACT, penelitian terdahulu terkait REACT, dan konsep pembuktian dalam matematika. Tahap perencanaan meliputi kegiatan pembuatan dan vaidasi instrument penelitian yaitu RPP dan lembar observasi keterlaksanaan pembelajaran berdasarkan kajian teori tentang strategi REACT. Tahap pelaksanaan merupakan tahapan pengambilan data kualitatif terkait penerapan strategi REACT dalam rangka mengembangkan kemampuan pembuktian matematis mahasiswa menggunakan instrumen yang telah dikembangkan pada tahap perencanaan.

Teknik pengumpulan data menggunakan observasi. Instrument yang digunakan dalam penelitian ini adalah RPP yang didesain menggunakan strategi REACT dan lembar observasi keterlaksanaan pembelajaran. Lembar observasi digunakan untuk mencatat aktivitas dosen dan mahasiswa selama proses pembelajaran menggunakan strategi REACT.

Teknik analisis data mengikuti (Ridder, Miles, Michael Huberman, \& Saldaña, 2014) yaitu (1) reduksi data. Reduksi data ini adalah mengklasifikasikan hasil pengamatan yang sesuai dengan kajian strategi REACT dalam kegiatan mengkonstruksi bukti, (2) penyajian data yaitu menyajikan data hasil reduksi dalam bentuk deskripsi, (3) penarikan kesimpulan sesuai dengan data dan hasil analisis.

\section{HASIL DAN PEMBAHASAN}

Penelitian ini bertujuan untuk mendiskripsikan penerapan strategi REACT pada mata kuliah Analisi Real dengan materi Sifat Aljabar pada Bilangan Real dimana data diambil menggunakan lembar observasi keterlaksanaan pembelajaran. Hasil observasi menyatakan bahwa strategi REACT dapat digunakan untuk mengembangkan kemampuan mengkonstruksi bukti matematis mahasiswa. Berikut rincian hasil pengamatan yang dilakukan oleh peneliti.

Kegiatan pertama adalah dosen meminta mahasiswa untuk membaca secara bermakna teorema 2.1.2 beserta pembuktiannya. Menurut (Vallori, 2014) membaca secara bermakna berpengaruh terhadap kemampuan ekplorasi siswa dalam memahami materi. Teorema 2.1.2 yang dimaksud ada pada Gambar 1.

2.1.2 Theorem (a) If $z$ and a are elements in $\mathbb{R}$ with $z+a=a$, then $z=0$.

(b) If $u$ and $b \neq 0$ are elements in $\mathbb{R}$ with $u \cdot b=b$, then $u=1$.

(c) If $a \in \mathbb{R}$, then $a, 0=0$.

Proof. (a) Using (A3), (A4), (A2), the hypothesis $z+a=a$, and (A4), we get

$$
z=z+0=z+(a+(-a))=(z+a)+(-a)=a+(-a)=0 .
$$

(b) Using (M3), (M4), (M2), the assumed equality $u \cdot b=b$, and (M4) again, we get

$$
u=u \cdot 1=u \cdot(b \cdot(1 / b))=(u \cdot b) \cdot(1 / b)=b \cdot(1 / b)=1 .
$$

(c) We have (why?)

$$
a+a \cdot 0=a \cdot 1+a \cdot 0=a \cdot(1+0)=a \cdot 1=a .
$$

Therefore, we conclude from (a) that $a \cdot 0=0$.

Gambar 1. Teorema keunikan bilangan 0 dan 1 
DOI: https://doi.org/10.24127/ajpm.v9i3.2950

Pada tahap ini aktivitas mahasiswa mulai terlihat diantaranya berdiskusi dan mencari literatur pendukung. Terdapat pertanyaan dari salah satu mahasiswa terkait proses pembuktian teorema bagian $\mathrm{c}$ yaitu mengapa diperoleh kesimpulan bahwa a. $0=0$. Dosen kemudian meminta mahasiswa untuk mengamati teorema bagian a kemudian menghubungkan dengan bagian c. Terlihat pada kegiatan ini dosen menggunakan strategi REACT pertama yaitu relating yang dalam hal ini memberi kesempatan kepada mahasiswa untuk menghubungkan teorema 2.1.2 a untuk memahami teorema 2.1 .2 c. Hasil dari kegiatan ini adalah mahasiswa dapat memahami proses pembuktian teorema $2.1 .2 \mathrm{c}$. Hal ini terlihat dari jawaban salah satu mahasiswa yang memisalkan $z=a .0$ pada bagian a. Sehingga dengan menggunakan teorema 2.1.2.a dan memisalkan $z=a .0$, teorema $2.1 .2 \mathrm{c}$ dapat dibuktikan. Hal ini sejalan dengan penelitian (Ersen, 2016) yang menyebutkan bahwa salah satu strategi pembuktian adalah dengan membandingkan bentuk argument dengan bentuk teorema yang relevan.

Strategi relating juga digunakan dosen untuk menjelaskan teorema 2.1.3 yaitu "jika $a . b=0$, maka $a=0$ atau $b=0$ ". Dosen meminta mahasiswa untuk menghubungkan dengan materi logika dasar yang telah diperoleh pada semester awal. Hal pertama yang dilakukan adalah mengubah bentuk teorema menjadi bentuk logika matematika kemudian memanipulasi bentuknya sehingga memberikan konklusi tunggal. Kegiatan ini berhasil karena mahasiswa dapat mengubah bentuk teorema tersebut menjadi "jika $a \cdot b=0$ dan $a=0$, maka $b=0$ " yang menghasilkan satu konklusi yaitu $b=$ 0 . Dengan begitu mahasiswa menjadi mudah dalam membuktikan. (Khusna, 2020) menyatakan bahwa mengubah dalam bentuk logika dasar merupakan salah satu strategi awal untuk mempermudah proses pembuktian.

Materi pembelajaran selanjutnya adalah membahas teorema 2.1.4 yaitu "tidak ada bilangan rasional $r$ sehingga $r^{2}=2$ ". Bukti teorema ini telah tersedia tetapi dalam bentuk deskripsi. Pada kesempatan ini dosen meminta mahasiswa untuk membuktikan kembali suatu argument yang telah tersedia buktinya dengan bahasa matematis. Aktifitas ini merupakan unsur experiencing dari strategi REACT. Terdapat pertanyaan dari mahasiswa tentang konsep FPB dan kaitannya dengan bentuk pecahan paling sederhana. Untuk menjawab permasalahan ini dosen memberikan penjelasan secara deduktif sebagai bagian dari bukti non formal. Hasil dari kegiatan ini adalah mahasiswa dapat memahami proses pembuktian sehingga menjadi lebih sederhana untuk dipahami serta mengerti mafaat dari pembuktian non formal untuk membantu alur berpikir ketika proses pembuktian. Hal ini sejalan dengan hasil penelitian (Basturk, 2010)(Komatsu, Tsujiyama, \& Sakamaki, 2014) yang menyatakan bahwa pembuktian secara non formal dapat membantu proses berpikir unutk menuju kepada proses pembuktian formal.

Kegiatan ketiga aktivitas applying yaitu dengan membuktikan suatu argument dimana bentuk argumennya sama dengan teoremateorema yang telah dipelajari. Berikut contoh argument yang harus dibuktikan oleh mahasiswa, yaitu:

Jika $a \in \mathbb{R}$ yang memenuhi a. $a=a$ buktikan bahwa $a=0$ atau $a=1$

Hal pertama yang dilakukan mahasiwa untuk membuktikan 
DOI: https://doi.org/10.24127/ajpm.v9i3.2950

argument di atas adalah menggunakan strategi merubah teorema kedalam bentuk logika matematika dengan memisalkan $a \cdot a=a$ adalah $p, a=0$ adalah $q$, dan $a=1$ adalah $s$. Bentuk logika matematikanya adalah $p \rightarrow$ $(q \vee r) \equiv \neg p \vee q \vee r \equiv(\neg p \vee q) \vee r \equiv$ $(p \wedge \neg q) \rightarrow r$. Selanjutnya mahasiswa mengolah premis yaitu $a \cdot a=a$ dan $a \neq 0$ sehingga menghasilkan konklusi $a=1$. Pada kegiatan applying ini mahasiswa berhasil membuktikan argument yang diberikan.

\section{Tabel 1. Implementasi strategi REACT}

\begin{tabular}{|c|c|c|c|}
\hline & $\begin{array}{c}\text { Kegiatan } \\
\text { pembelajaran }\end{array}$ & $\begin{array}{c}\text { Unsur } \\
\text { REACT }\end{array}$ & $\begin{array}{c}\text { Perkembangan Kemampuan } \\
\text { Mengkonstruksi Bukti }\end{array}$ \\
\hline 1. & $\begin{array}{l}\text { Memahami teorema } 2.1 .2 \\
\text { terkait keunikan bilangan } \\
1 \text { dan } 0 .\end{array}$ & Relating & \begin{tabular}{lccc} 
Mahasiswa & mampu & \multicolumn{2}{c}{ mengaplikasikan } \\
teorema sebelumnya & sehingga dapat \\
menemukan strategi & pembuktian yang \\
digunakan. & & &
\end{tabular} \\
\hline 2. & Memahami teorema 2.1.3 & Relating & $\begin{array}{l}\text { Mahasiswa mampu menemukan strategi } \\
\text { pembuktian melalui manipulasi logika } \\
\text { matematika. }\end{array}$ \\
\hline 3. & $\begin{array}{l}\text { Memahami teorema } 2.1 .4 \\
\text { tentang tidak ada } \\
\text { bilangan rasional yang } \\
\text { kuadratnya sama dengan } \\
2\end{array}$ & Experiencing & $\begin{array}{l}\text { Mahasiswa mampu menuliskan kembali } \\
\text { bukti menggunakan bahasa sendiri } \\
\text { menggunakan simbol matematika. } \\
\text { Mahasiswa mampu menggunakan bukti } \\
\text { non formal sebagai strategi untuk } \\
\text { membantu menentukan langkah } \\
\text { pembuktian selanjutnya. }\end{array}$ \\
\hline 4. & $\begin{array}{l}\text { Membuktikan teorema } \\
\text { yang bentuknya sama } \\
\text { dengan teorema } 2.1 .3\end{array}$ & Applying & $\begin{array}{l}\text { Mampu membuktikan dengan } \\
\text { menerapkan strategi manipulasi bentuk } \\
\text { logika matematikanya. }\end{array}$ \\
\hline 5. & $\begin{array}{l}\text { Kegiatan berdiskusi pada } \\
\text { teorema } 2.1 .2,2.1 .3 \text {, dan } \\
2.1 .4\end{array}$ & Coorperating & $\begin{array}{l}\text { Dapat mengoreksi, mencari teorema yang } \\
\text { terkait untuk mendukung proses } \\
\text { pembuktian. }\end{array}$ \\
\hline 6. & $\begin{array}{lr}\text { Membuktikan } & \text { teorema } \\
\text { yang } & \text { merupakan } \\
\text { pengambangan } & \text { dari } \\
\text { teorema } 2.1 .4 & \end{array}$ & Transferring & $\begin{array}{l}\text { Mahasiswa dapat membuktikan } \\
\text { menggunakan bukti tak langsung } \\
\text { (kontradiksi) serta dapat menghubungkan } \\
\text { konsep bilangan ganjil dan genap untuk } \\
\text { menentukan letak kontradiksinya. }\end{array}$ \\
\hline
\end{tabular}

Kegiatan pembelajaran didesain dosen pembelajaran berkelompok. Menurut (Chen, Yang, \& Hsiao, 2016) dengan berdiskusi permasalahan matematika dapat dilihat dari berbagai sudut pandang sehingga semakin mudah untuk diselesaikan. Secara tidak langsung akan terbentuk kerja sama atau cooperating antar mahasiswa dalam memahami maupun menyelesaian masalah pembuktian yang diberikan oleh dosen. Bentuk kerja sama terlihat ketika antar anggota kelompok saling mengoreksi proses pembuktian dan salin membantu dalam mencari teorema atau konsep lain untuk mendukung proses pembuktian. Manfaat lain adalah dosen dapat memberikan scaffolding dengan mudah dan cepat (van de Pol, Mercer, \& Volman, 2019)

Kegiatan terakhir adalah pemberian latihan soal berupa argumen yang memiliki bentuk berbeda dengan 
teorema yang telah dipelajari. Hal ini termasuk kegiatan transferring yaitu pemberian masalah dalam konteks baru. Argumen tantangan yang diberika adalah "buktikan bahwa tidak ada bilangan rasional $s$ sehingga $s^{2}=6$ " dimana soal ini merupakan pengembangan dari teorema 2.1.4 yang telah dipelajari. Pada kegiatan transferring ini ada sedikit kendala dimana mahasiswa berhenti pada saat melakukan verifikasi terkait nilai variable $x^{2}$. Kemudian dosen memberikan pertanyaan pancingan yaitu " $2 \mathrm{~m}^{2}$ itu bilangan genap atau ganjil?". Mahasiswa menjawab "genap bu. Kalau begitu $3 x^{2}$ adalah genap. Kalau 3 itu ganjil maka $x^{2}$ ya harus genap". Dari berbagai diskusi tersebut akhirnya mahasiswa dapat menemukan kontradiksinya.

Implementasi strategi REACT untuk mengembangkan kemampuan mahasiswa dalam mengkonstruksi bukti secara umum terangkum dalam Tabel 1. Secara keseluruhan, penggunaan strategi REACT pada mata kuliah Analisis Real ini berpengaruh terhadap kemampuan mahasiswa dalam mengkonstruksi bukti terutama pada materi sifat aljabar. Kelebihan strategi REACT ini adalah setiap tahapannya sistematis sehingga mahasiswa terlatih untuk berpikir secara logis dan runtut. Hal ini berdampak pada kemampuan mahasiswa dalam menentukan strategi yang tepat dalam mengkonstruksi bukti (Viseu, Menezes, Fernandes, Gomes, \& Martins, 2017) . Selain itu mahasiswa dapat menghubungkan konsep logika dasar dalam proses pembuktian. Hal ini penting agar proses pembuktian yang dilakukan sistematis dan tidak terjadi ambiguitas premis dan konklusi. (Miyazaki, Fujita, \& Jones, 2017) mengatakan bahwa pemahaman terhadap prinsip logika dapat membantu mahasiswa untuk fokus peran premis dan konklusi suatu pernyataan matematis sehingga lebih mudah dalam melakukan pembuktian. Selain itu penerapan strategi REACT mendapatkan respon yang positif dari mahasiswa. Hal ini terlihat dari antusiasme mahasiswa dalam bertanya, berdiskusi, serta aktif dalam mengkonstruksi bukti selama kegiatan pembelajaran berlangsung.

\section{KESIMPULAN DAN SARAN}

Berdasarkan hasil observasi selama proses pembelajaran, diperoleh kesimpulan bahwa pembelajaran dengan strategi REACT dapat digunakan untuk mengembangkan kemampuan mahasiswa dalam mengkonstruksi bukti. Strategi yang diberikan berupa memberi kesempatan kepada mahasiswa untuk menghubungkan teorema satu dengan teorema lain (Relating), menuliskan kembali bukti sesuai dengan bahasa sendiri dan penggunaan bukti non formal sebagai bantuan (Experiencing), memanipulasi bentuk pernytaan berdasarkan prinsip logika dasar (Applying), saling memeriksa kebenaran proses pembuktian (Cooperating), dan membuktikan pernyataan yang dikembangkan (Transferring). REACT berdampak pada berkembangnya kemampuan mahasiswa dalam mengonstruksi bukti. Selain itu penerapan strategi REACT mendapatkan respon yang positif dari mahasiswa. Saran dari penelitian ini perlu adanya penelitian lanjutan terkait pengembangan media baik cetak maupun non cetak berbasis pendekatan REACT untuk mengembangkan kemampuan mengkonstruksi bukti. 
DOI: https://doi.org/10.24127/ajpm.v9i3.2950

\section{DAFTAR PUSTAKA}

Basturk, S. (2010). First-year secondary school mathematics students' conceptions of mathematical proofs and proving. Educational Studies, 36(3), 283-298. https://doi.org/10.1080/030556909 03424964

Bell, A. W. (1976). A study of pupils' proof-explanations in mathematical situations. Educational Studies in Mathematics, 7(2), 23-40. https://doi.org/10.1007/BF0014435 6

Chen, S. C., Yang, S. J. H., \& Hsiao, C. C. (2016). Exploring student perceptions, learning outcome and gender differences in a flipped mathematics course. British Journal of Educational Technology, 47(6), 1-17. https://doi.org/10.1111/bjet.12278

Crawford, M. L. (2001). Teaching Contextually. Waco, Texas: CCI Publising, Inc.

Dogan, M. F. (2019). The Nature of Middle School In-Service Teachers' Engagements in Proving-Related Activities. Cukurova University Faculty of Education Journal, 48(1), 100130.

https://doi.org/10.14812/cufej.4428 93

Ersen, Z. B. (2016). Preservice Mathematics Teachers' Metaphorical Perceptions towards Proof and Proving. International Education Studies, 9(7), 88. https://doi.org/10.5539/ies.v9n7p8 8
Hammack, R. (2013). Book of Proof. i-x 1-303. Retrieved from http://www.people.vcu.edu/ rham mack/BookOfProof/

Healy, L., \& Hoyles, C. (2000). A study of proof conceptions in algebra. Journal for Research in Mathematics Education, 31(4), 396-428. https://doi.org/10.2307/749651

Jelatu, S., Sariyasa, \& Made Ardana, I. (2018). Effect of GeoGebra-aided REACT strategy on understanding of geometry concepts. International Journal of Instruction, 11(4), 325-336. https://doi.org/10.12973/iji.2018.1 $1421 \mathrm{a}$

Khusna, A. H. (2020). Analytical thinking process of student in proving mathematical argument. International Journal of Scientific and Technology Research, 9(1), 1248-1251.

Ko, Y. Y. (2010, December). Mathematics Teachers' Conceptions of Proof: Implications for Educational Research. International Journal of Science and Mathematics Education, Vol. 8, pp. 1109-1129. https://doi.org/10.1007/s10763010-9235-2

Komatsu, K., Tsujiyama, Y., \& Sakamaki, A. (2014). Rethinking the discovery function of proof within the context of proofs and refutations. International Journal of Mathematical Education in Science and Technology, 45(7), 1053-1067. https://doi.org/10.1080/0020739X. 2014.902135 
Lesseig, K., Hine, G., Na, G. S., \& Boardman, K. (2019). Perceptions on proof and the teaching of proof: a comparison across preservice secondary teachers in Australia, USA and Korea. Mathematics Education Research Journal, 31(4), 393-418. https://doi.org/10.1007/s13394019-00260-7

Miyazaki, M., Fujita, T., \& Jones, K. (2017). Students' understanding of the structure of deductive proof. Educational Studies in Mathematics, 94(2), 223-239. https://doi.org/10.1007/s10649016-9720-9

Pantaleon, K. V., Juniati, D., \& Lukito, A. (2018). The proving skill profile of prospective math teacher with high math ability and high math anxiety. Journal of Physics: Conference Series 1097, 1-5. https://doi.org/10.1088/17426596/1097/1/012154

Reyhani, E., Hamidi, F., \& Kolahdouz, F. (2012). A study on algebraic proof conception of high school second graders. Procedia - Social and Behavioral Sciences. https://doi.org/10.1016/j.sbspro.20 11.12.048

Ridder, H. G., Miles, M. B., Michael Huberman, A., \& Saldaña, J. (2014). Qualitative data analysis. A methods sourcebook. In Zeitschrift fur Personalforschung (3rd ed., Vol. 28 ). https://doi.org/10.1177/239700221 402800402
Sari, D. P., \& Darhim. (2020). Implementation of react strategy to develop mathematical representation, reasoning, and disposition ability. Journal on Mathematics Education, 11(1), 145-156.

https://doi.org/10.22342/jme.11.1.7 806.145-156

Soma Salim, S. (2019). Reasoning-andproving and world-related problems in the mathematics textbook of Kurikulum 2013 revised in 2017. Journal of Physics: Conference Series. https://doi.org/10.1088/17426596/1317/1/012126

Sørensen, H. K., Danielsen, K., \& Andersen, L. E. (2019). Teaching reader engagement as an aspect of proof. ZDM - Mathematics Education, 51(5), 835-844. https://doi.org/10.1007/s11858019-01056-6

Srivastava, A., \& Sutton, C. (2016). Neural Variational Inference for Topic Models. ArXiv Preprint, 1(1), 1-12.

Stylianides, G. J. (2009). Reasoningand-proving in school mathematics textbooks. Mathematical Thinking and Learning. https://doi.org/10.1080/109860609 03253954

Switala, M. S. (2019). Enacting Reasoning-and-Proving in Secondary Mathematics Classrooms through Tasks. Journal of Chemical Information and Modeling, 53(9), 1689-1699. 
DOI: https://doi.org/10.24127/ajpm.v9i3.2950

Syah Aji, R. H. (2014). KHAZANAH SAINS DAN MATEMATIKA DALAM ISLAM. SALAM: Jurnal Sosial Dan Budaya Syar-I, 1(1), 155-168.

https://doi.org/10.15408/sjsbs.v1i1. 1534

Tall, D. (1995). Cognitive development, representations and proof. $A$ Conference on Institute of Education of London, (December), 27-38. Retrieved from http://www.warwick.ac.uk/staff/Da vid.Tall/pdfs/dot1995f-repnsproof.pdf

Tambychik, T., \& Meerah, T. S. M. (2010). Students' difficulties in mathematics problem-solving: What do they say? Procedia Social and Behavioral Sciences, 142-151.

https://doi.org/10.1016/j.sbspro.20 10.12.020

Ültay, N., Durukan, Ü. G., \& Ültay, E. (2015). Evaluation of the effectiveness of conceptual change texts in the REACT strategy. Chemistry Education Research and Practice, 16(1), 22-38.

Vallori, A. B. (2014). Meaningful Learning in Practice. Journal of Education and Human Development, 3(4), 199-209. https://doi.org/10.15640/jehd.v3n4 a18

van de Pol, J., Mercer, N., \& Volman, M. (2019). Scaffolding Student Understanding in Small-Group Work: Students' Uptake of Teacher Support in Subsequent Small-Group Interaction. Journal of the Learning Sciences. https://doi.org/10.1080/10508406.2 018.1522258

Verschaffel, L., Depaepe, F., \& De Corte, E. (2015). Mathematics Education. In International Encyclopedia of the Social \& Behavioral Sciences: Second Edition (pp. 816-821). https://doi.org/10.1016/B978-0-08097086-8.92048-8

Viholainen, A., Tossavainen, T., Viitala, H., \& Johansson, M. (2019). University mathematics students' self-efficacy beliefs about proof and proving. LUMAT, 7(1), 148-164. https://doi.org/10.31129/LUMAT. 7.1.406

Viseu, F., Menezes, L., Fernandes, J. A., Gomes, A., \& Martins, P. M. (2017). Conceptions of basic education teachers about math proof: Influence of professional experience. Bolema - Mathematics Education Bulletin, 31(57), 430453. https://doi.org/10.1590/1980$4415 \mathrm{v} 31 \mathrm{n} 57 \mathrm{a} 21$

Weinberg, P. (2019). Generalizing and proving in an elementary mathematics teacher education program: Moving beyond logic. Eurasia Journal of Mathematics, Science and Technology Education, 15(9), 1-15. https://doi.org/10.29333/ejmste/10 8450 